\title{
FINANCIAL ENGINEERING SEBAGAI INSTRUMEN AKTIVITAS HEDGING
}

Oleh:

Sukardi *)

\section{ABSTRAK}

Tujuan penulisan artikel ini adalah menyajikan uraian tentang produk hasil perekayasaan keuangan, dan menunjukkan fungsinya sebagai instrumen dalam mengendalikan risiko atau aktivitas hedging, serta memperlihatkan penyajian disclosurenya dalam laporan keuangan. Penyajian disclosure ini dianggap penting karena disclosure dapat memberikan pemahaman pada pembaca laporan keuangan khususnya investor tentang kebijakan manajemen dalam mengendalikan risiko perusahaan sehingga investor tidak akan tersesat dalam membuat kebijakan investasinya.

Kata kunci : financial engineering, hedging, disclosure,

\section{A. PENDAHULUAN}

Perekayasaan keuangan (financial engineering) adalah suatu perencanaan, pengembangan, dan implementasi proses inovasi instrumen keuangan, dan pembentukan formulasi untuk menyelesaikan permasalahan dalam bidang keuangan( Finnerty 1988). Inti definisi ini terletak pada kata inovasi, yang mengandung arti bahwa instrumen keuangan harus menunjukkan suatu temuan baru dalam bidang keuangan, yang mampu memperbaiki kinerja secara dramatik, bukan secara marginal. Selanjutnya, instrumen keuangan berfungsi strategi bagi manajemen yang diterapkan untuk menciptakan nilai tambah dan kinerja yang lebih baik bagi penyelesaian permasalahan keuangan. Oleh karena itu, istilah perekayaan dan inovasi keuangan seringkali dianggap sebagai istilah yang sepadan.

Tujuan pembentukan instrumen keuangan tersebut adalah sebagai alat untuk mengendalikan risiko perusahaan yang disebabkan oleh adanya perubahan dalam harga, tingkat bunga, dan tingkat pertukaran mata uang asing (White dkk. 1997). Sedangkan, faktor-faktor yang berkontribusi pada timbulnya perekayasaan keuangan secara dramatik menurut Marshal dan Bansal (1992) meliputi faktorfaktor lingkungan eksternal perusahaan dan internal perusahaan. Faktor-faktor eksternal ini dipicu oleh tekanan persaingan industri yang sejenis serta perkembangan pasar yang semakin sulit dikendalikan seperti peraturan akuntansi dan perpajakan yang semakin berkembang, perkembangan teknologi informasi, volatilitas harga dan sebagainya. Sedangkan faktor internal perusahaan dipengaruhi oleh kebijakan internal perusahaan, seperti kemampuan analisis kuantitatif diantara manajer investasi, pendidikan formal dan training pada personal untuk level senior perusahaan, adanya penolakan risiko diantara manajer

\footnotetext{
") Sukärdi, SE, M. Si adalah Dosen Tetap Program D-3 Fakultas Ekonomi Universitas Islam Indonesia (UII)
} 
dan pemegang saham, dan biaya agensi (agency costs).

Sejalan dengan pemikiran Marshal dan Bansal ini, Miller (1992) berargumentasi bahwa instrumen keuangan sebagai hasil perekayasaan bidang keuangan disebut juga sebagai inovasi keuangan. Inovasi keuangan ini mulai berkembang sekitar tahun 1970an. Motivasi perkembangan inovasi keuangan menurut dia dipengaruhi oleh beberapa faktor, yaitu pergerakan tingkat pertukaran mata uang dari tingkat pertukaran tetap (fixed rate ex-change) pada tingkat pertukaran mengambang (floating rate exchange), Perkembangan teknologi informasi dan computer, Pertumbuhan ekonomi dunia dan regulasi dan deregulasi bidang struktur keuangan.

Berdasarkan uraian di atas maka dalam artikel ini akan disajikan uraian tentang produk hasil perekayasaan keuangan, dan menunjukkan fungsinya sebagai instrumen dalam mengendalikan risiko atau aktivitas hedging, serta mempertihatkan penyajian disclosurenya dalam laporan keuangan.

Instrumen keuangan sebagai hasil dari suatu perekayasaan sangat beragam dari yang sederhana sampai dengan yang sangat kompleks. Menurut Finnerty (1988), instrumen keuangan sebagai hasil dari suatu perekayasaan dapat dikelompokkan menjadi tiga kelompok, yaitu:

1. Instrumen keuangan, yang meliputi: tipe konsumen (seperti money market mutual funds, money market accounts, NOW. account, bull/bear CDs, dil), tipe sekuritas (seperti stripped debt securities, floating rate, rating sensitivitas notes, foreign currency futures, forward rate agreements dil), tipe proses keuangan (seperti direct publis sale of securities, automated teller machines, CHIPS, dII), tipe strategi keuangan (seperti debt-for debt-exchange, hedged dividend capture, insubstance defeasance, dan corporate restructuring).

2. Instrumen common equity, yang meliputi: additional class(es) of common stock, americus trust, master limited, dan puitable common stock.

3. Instrumen convertible debt/preferred stock, yang meliputi: adjustable rate convertible debt, convertible exchange preferred stock, convertible reset debentures, debt with mandatory common stock purchase contracts, dil (lihat Finnerty 1988).

Produk perekayasaan instrumen keuangan dalam beberapa literatur lainnya disebut juga sebagai produk derivatif, yang sifatnya tidak terlepas dari perkembangan pasar modal atau bursa yang ada pada suatu negara. Di dunia saat ini diperkirakan sudah terdapat 1200-an produk derivatif (Sumual, 1998). Meskipun produk derivatif sangat besar jumlahnya, namun bila ditelusuri lebih detail maka produk derivatif yang utama adalah hanya terdiri dari 4 produk derivatif, yaitu: a) forward contracts, b) futures contracs, c) swap contracts, dan d) option contracts (Smithson dan Smith 1990). Dari produk utama ini dapat dibentuk berbagai jenis diversifikasi produk derivatif. Pembentukan' ini dapat dilakukan dengan metode Building Blocks (Smithson dan Smith 1990). Tujuan pembentukan produk derivatif ini adalah sebagai dasar strategi dalam mengelola risiko, yang diharapkan dapat mencapai perfect hedge, sehingga mampu untuk mengeliminasi risiko secara penuh. 
Menurut Smith (1993) peranan pembentukan instrumen keuangan ini adalah mengkombinasikan instrumen-instrumen keuangan yang ada dalam rangka mencapai suatu risk-return yang tidak tersedia pada instrumen yang lainnya. Namun demikian, sebagian besar produk-produk tersebut belum banyak dikenal di Indonesia. Secara umum, produk derivatif yang sudah terkenal adalah: a) derivatif dalam bidang suku bunga, yang meliputi: forward rate agreement (FRA), interest rate swap, currency, caps, floors, dan collars .b) Derivatif dalam pasar modal yang terkenal meliputi call options, put options, swap, future contract, forward index, future index, dan lain-lain. Bentuk instrumen keuangan hasil perekayasaan ini dapat diperdagangkan dipasar yang telah ditentukan, yaitu bursa option, bursa saham, dan bursa future. Perkembangan instrumen keuangan saat ini sudah berparalel dengan peningkatan volatilitas harga, tingkat bunga, dan tingkat pertukaran mata uang asing dalam pasar keuangan. Oleh karena itu, perkembangan pasar keuangan akan memacu semakin berkembangnya instrumen keuangan yang sesuai untuk aktivitas hedging, sehingga perusahaan akan semakin mempunyai banyak pilihan dalam menggunakan teknik-teknik hedging dalam mengendalikan exposure risikonya.

\section{RISIKO KEUANGAN PERUSAHAAN}

Risiko keuangan perusahaan terjadi karena adanya realisasi pergerakan harga komoditas, tingkat bunga, dan tingkat pertukaran mata uang asing yang arahnya berlawanan dengan kebijakan manajemen perusahaan. Risiko mata uang asing terjadi pada perusahaan yang beroperasi di berbagai negara yang berlainan mata uangnya. Risiko ini muncul karena adanya perubahan dalam tingkat pertukaran mata uangnya. Pengaruh perubahan pertukaran mata uang ini akan berdampak pada laporan laba-rugi, anus kas, dan neraca sehingga rasio keuangan juga akan berubah. Karena risiko ini sangat berpengaruh pada kinerja akuntansi perusahaan maka risiko ini dapat disebut dengan risiko akuntansi (White dkk. 1997).

Risiko tingkat bunga terjadi pada perusahaan yang meminjam dana dari pihak lain. Bunga atas dana pinjaman tersebut dapat bersifat tetap atau variabel. Ketika tingkat bunga adalah variabel, maka biaya bunga masa depan dan bunga yang dibayarkan bersifat tidak pasti jumlahnya: Jumlah ini tergantung pada tingkat level referensi yang digunakan dimasa depan. Kondisi ini akan menimbulkan satu risiko ketidakpastian karena biaya bunga yang akan dibayarkan dimasa depan (bagi peminjam/debitor), dan pendapatan bunga dimasa depan, serta bunga yang diterima (bagi kreditor) menjadi tidak pasti jumlahnya. Karakteristik bunga yang bersifat variabel ini merupakan kebalikan dari tingkat bunga tetap.

Risiko lainnya yang dihadapi perusahaan adalah risiko komoditas, yaitu risiko yang terjadi pada perusahaan yang tidak mampu mengendalikan harga jual produknya sehingga harga produk dimasa depan menjadi tidak pasti. Dengan tidak adanya kepastian harga ini maka akan menimbulkan satu risiko keuangan perusahaan dimasa depan. Risiko ini berdampak besar pada operasi perusahaan secara keselunuhan.

Risiko berikutnya yang perlu dikendalikan perusahaan adalah risiko adanya perubahan dalam nilai pasar. Risiko ini terjadi karena fluktuasi dalam tingkat pertukaran mata uang asing, tingkat bunga, dan harga komoditas, yang berpengaruh pada nilai pasar aktiva dan hutang perusahaan'(White dkk 1997). 
Hedging dirancang untuk melindungi perusahaan terhadap realisasi pergerakan harga, tingkat bunga, dan tingkat pertukaran mata uang asing yang arahnya berlawanan dengan yang diharapkan oleh manajemen perusahaan. Transaksi derivatif yang umumnya digunakan dalam aktivitas hedging meliputi (tetapi tidak terbatas pada) kontrak futures, option, komitmen forward, swaps tingkat bunga, swaps mata uang, dan kombinasi swaps mata uang dan tingkat bunga (White dkk. 1997).

Aktivitas hedging berfungsi untuk mengendalikan atau menurunkan risiko atas harga, tingkat bunga, tingkat perubahan mata uang yang berkaitan dengan: 1. Transaksi pembelian dan (atau) penjualan aktiva berwujud seperti komoditas.

2. Transaksi pembelian dan (atau) penjulan aktiva yang disertai dengan tingkat bunga dan (atau) exposure mata uang.

3. Transaksi atas hutang dengan tingkat bunga dan (atau) exposure mata uang.

4. Komitmen perusahaan untuk membeli dan (atau) menjual bahan baku atau instrumen keuangan, dana pinjaman, atau pelunasan hutang,

5. Peramalan transaksi (forecasted transaction) seperti akuisisi dan pengembalian dana (repratri-ation of funds).

White dkk. (1997) mengelompokkan teknik-teknik hedging menjadi dua, yaitu: a) teknik hedge derivatif, dan b) teknik natural hedge. Teknik hedge derivatif dilakukan dengan instrumen sebagai berikut: (1) Kontrak-Kontrak Fonward. Teknik ini adalah satu cara untuk mengeliminasi risiko harga atas transaksi dimasa depan yaitu dengan menetapkan harga transaksi didepán. Kontrak forward menetapkan tujuannya atas sesuatu dimasa depan dalam|kaitannya pada: (a) jumlah dan sifat transaksi, (b) tanggal jatuh tempo, dan (c) harga. Kontrak forward merupakan kontrak yang bersifat khusus antara pembeli dan penjual dan sering kali dilakukan untuk memenuhi kebuțuhan pembeli tersebut. Antara pembeli dan penjual keduanya menanggung suatu risiko yaitu counterparty risk.

Counterparty risk adalah risiko bahwa pihak yang lain pada kontrak forward tidak akan melakukan kewa-jibannya sesuai dengan końtrak (defauit). Untuk menghindari counterparty risk ini, pihak-pihak yang terkait dalam kontrak forward dapat melakukan evaluasi atas risiko kredit pada pihák lainnya, jika perlu kontrak forward mensyaratkan adanya jaminan dalam perjanjian kontraknya. Dalam perjanjian kontrak forward pihak yang terkait juga diperbolehkan untuk menggunakan perjanjian yang sudah distandarisasikan yang memungkinkan mereka untuk mengimbangi expo-sure risiko dengan satu counterparty khusus.

Kontrak-kontrak future adalah kontrak-kontrak forward yang sudah distandarisasikan, yang secara normal diperdagangkan pada bursa komoditas yang terorganisasi secara resmi. Pihak yang menanggung counterparty risk diantara kedua belah pihak antara pembeli dan penjual disebut dengan exchange clearinghouse. Dengan alasan bahwa kontrak future telah tercatat di bursa diperdagangkan secara harian (marked to market), maka kontrak future ini meminta syarat jaminan tambahan (margin) dari pihak yang berkontrak untuk menanggung satu kerugian pada kontrak tersebut.

Bentuk lain dari kontrak forward adalah swaps. Swaps adalah kombinasi kontrak-kontrak forward. Dalam satu swap tingkat bunga (interest rate swap), 
satu pihak berjanji untuk membayar pada pihak lain satu tingkat bunga tetap pada satu jumlah nominal tertentu atas pembayaran dalam pelunasan bunga yang telah ditetapkan dengain satu tingkat bunga variabel dalam suatu perjanjian kredit. Persetujuan ini meliputi dua kontrak, yaitu: satu pihak menutup pembayaran bunga pada tingkat tetap, pihak lainnya melakukan pembayaran tingkat variabel. Swap juga sering digunakan untuk mata uang asing seperti juga pada tingkat bunga. Swap tingkat bunga dan mata.uang asing dapat juga digunakan secara bersama-sama dalam satu kontrak.

Option memberikan pada pihak lain untuk membeli (call) atau menjual (put) sejumlah hak yang khusus pada harga yang pasti sampai dengan satu tanggal jatuh tempo yang sudah ditetapkan. Option ini sifatnya lebih fleksibel jika dibandingkan dengan kontrak forward yang mengharuskan untuk dilaksanakan (exercised) pada saat jatuh temponya (bahkan ketika transaksi bersifat tidak menguntungkan sekalipun). Namun dalam satu option, pemegangnya diberikan . satu kebebasan untuk melaksanakan transaksi atau tidak melaksanakan transaksi berdasarkan option tersebut. Jika option tersebut menguntungkan (ada laba) pada saat jatuh tempo, maka option dapat dilaksanakan transaksinya (exercised). Namun, jika option tersebut tidak memberikan keuntungkan (tidak ada laba) pada saat jatuh tempo bagi pemegangnya, maka option dapat tidak dilaksanakan transaksinya dán dilewatkan begitu saja. Misalnya, satu call option dengan harga atas aktiva yang menjadi underlying-nya (strike price) diatas harga pasar pada saat jatuh tempo, maka option tersebut dapat dilewatkan saja tanpa dilaksa-nakan transaksinya (tidak di-exercise). Demikian juga, jika put option dengan strike price dibawah harga pasar pada saat jatuh tempo, maka option tersebut dapat dilewatkan saja tanpa di-exercise. Sebaliknya, bila call option dengan strike price dibawah harga pasar pada saat jatuh tempo, dan put option dengan strike price diatas harga pasar, maka option ini akan di-exercise pada saat jatuh temponya, karena ada selisih harga yang menguntungkan pemegangnya. Pembeli option akan membayar satu premium pada penjualnya yang berfungsi sebagai ganti dari harga risiko. Jika option tersebut tidak diexercise, maka premium akan hilang dan menjadi biaya. Bursa perdagangan option, seperti juga futures, tidak mempunyai counterparty risk. Namun demikian, ketika persetujuan option adalah bersifat pribadi, maka pembeli harus mempertimbangkan counterparty risk. Penjual yang menerima premium pada awal transaksi juga tidak mempunyai risiko.

Teknik natural hedge disebut juga dengan economic hedge. Teknik hedge ini digunakan ketika pengaruh perubahan satu harga pada satu perusahaan saling berimbang (offset) pada har-ga yang lainnya. Perubahan harga input (harga beli) dapat secara langsung berpengaruh langsung pada harga out (harga jual) pada konsumennya. Teknik economic hedge yang sebenamya (pure economic hedge) dilakukan melalui. suatu perijinan khusus dari pemerintah suatu negara agar penusahaan dapat melakukan perubahan harga dari harga input ke harga outputnya secara otomatis. Tujuan economic hedge ini adalah supaya perubahan harga yang terjadi tidak berpengarun signifikan pada laba perusahaan. Perubahan harga yang tidak berpengaruh signifikan pada laba penusahaan terjadi jika perubahan harga input yang berdampak pada biaya operasi penusahaan mempunyai jumlah yang relatif sama dengan perubahan harga out pada pelanggannya yang 
berpengaruh pada pendapatan perusahaan yang bersangkutan.

Pada umumnya perusahaan yang melakukan teknik hedge ini adalah perusahaan yang menghasilkan produk bersifat menguasai hajat hidup orang banyak dimasyarakat, seperti perusahaan penyulingan minyak dan gas bumi. Namun demikian penerapan teknik economic hedge secara murni jarang sekali dilakukan. Penerapan yang lebih umum adalah perubahan harga output yang merefleksikan adanya perubahan harga input, sehingga perubahan harga yang terjadi masih menunjukkan dampak pada laba perusahaan, yang disebabkan oleh perbedaan waktu (time lag) dalam pelaksanaan perubahan harga antara input dan output maupun selisih (spread) antara harga input dan output yang berfluktuasi. Adanya perbedaan waktu dan selisih harga ini akan membuat laba perusahaan menjadi sangat berfluktuasi atau ber-volatile. Oleh karena itu, perusahaan perfu menerapkan teknik economic hedge secara modifikasi. Menurut White dkk (1997) teknik ini meliputi: (1) Interest Rate Matching dan (2) Foreign Currency Matching. Teknik yang pertama ini sesuai untuk perusahaan keuangan. Manajemen perusahaan keuangan selalu mencurahkan perhatiannya pada faktorfaktor yang dapat dipertimbangkan dapat mempengaruhi perubahan tingkat bunga. $\mathrm{Hal}$ ini dikarenakan bahwa perusahaan keuangan ini secara umum ingin memperoleh dan mempertahankan satu selish bunga (spread) yang relatif tetap antara pendapatan bunga dengan biaya pendanaannya (cost of fund berupa biaya bunga). Oleh karena itu, manajemen perusahaan harus peduli pada kedua faktor berikut ini: (1) kebijakan tingkat bunga atas penya-luran kredit maupun sumber pendanaannya apakah menggunakan tarip tetap atau variabel, dan (2) jangka waktu (duration) atas kredit dan sumber pendanaannya. Perusahaan keuangan selalu mencari kesesuaian sensitivitas tingkat bunganya atas kredit yang disalurkan dengan tingkat bunga untuk sumber pendanaannya. Apabila terjadi ketidaksesuaian (mismatch) antara tingkat bunga kredit yang disalurkan dengan tingkat untuk sumber pendanaannya, maka manajemen dapat meralatnya dengan menggunakan instrumen derivatif seperti kontrak forward dan option.

Foreign Currency Matching sangat cocok untuk perusahaan multinasional yang umumnya mempunyai aktiva dan hutang dalam banyak mata uang asing. Perusahaan ini dapat meminimalkan penganuh perubahan tingkat pertukaran mata uang asing pada modal anak perusahaannya dengan cara meminimalkan exposure-nya pada mata uang yang spesifik, yang secara khusus diharapkan dapat menurunkan exposure risiko atas perubahan tingkat pertukaran mata uang asing tersebut. Salah satu cara yang dapat ditempuh adalah dengan melakukan pinjaman pada mata uang dari suatu negara yang bersifat lemah, menurunkan exposure aktiva bersih (berkaitan dengan transiation) atau net monetory exposure (berkaitan dengan pengukuran). Dengan cara ini maka pendapatan dan biaya dapat dipadukan dengan cara menyamakan jumlahnya (similarly), walaupun hal ini sulit untuk dilak-sanakan untuk anak perusahaan transaksinya banyak yang saling terkait secara bersilang (cross-border transactions). Ketika aliran kas cross-border tidak biasa dilakukan antisipasi, maka instrumen derivatif dapat digunakan dengan menetapkan (fix) tingkat pertukaran mata uang tersebut. 
Sebelumnya membahas masalah disclosure atas aktivitas hedging, permasalahan akuntansi yang terkait dengan aktivitas hedging perlu dipahami terlebih dahulu karena keduanya saling terkait. Pembahasan akuntansi yang terkait dengan aktivitas hedging dibatasi pada permasalahan: 1) Pengakuan (Recognition), 2) Pengukuran (Measurement), dan 3) Forecasted Transaction.

Masalah akuntansi pokok dalam aktivitas hedging adalah waktu pengakuan keuntungan dan kerugian hedge dan pada faktor yang mendasari (underlying) aktiva atau hutang, komitmen perusahaan, atau transaksi yang diantisipasi dengan hedge. Menurut SFAS 80 , ada dua kriteria yang harus dipenuhi dari satu instrumen untuk dapat dikategorikan sebagai satu hedge, yaitu: a) item yang di-hedge dapat menunjukkan pada satu perusahaan dengan tingkat bunga atau risiko harga yang pasti, b) instrumen hedging menurunkan exposure dan dirancang sebagai satu hedge.

Ketika satu instrumen berkualifikasi sebagai satu hedge, maka keuntungan dan kerugian pada instrumen tersebut harus diakui secara bersamaan waktunya dengan item yang di-hedge tersebut. Dalam beberapa kasus, keuntungan dan kerugian pada item yang di-hedge dapat dilaporkan dalam cadangan penilaian dalam bagian ekuitas, sebagai contoh investasi bersih pada anak perusahaan di luar negeri dan investasi jangka panjang dalam sekuritas. Keuntungan dan kerugian dari beberapa item yang di-hedge harus juga dilaporkan dengan cara yang sama. Instrumen hedging yang tidak memenuhi syarat hedge adalah instrumen hedging yang diberi tanda "marked to market" (diperdagangkan di pasar keuangan) dan diakui sebagai aktiva atau hutang pada setiap tanggal laporan keuangan. Keuntungan dan kerugian yang ada akan dilaporkan pada laba bersih.

Masalah pengukuran yang fundamental atas aktivitas hedging adalah berkaitan dengan nilai yang harus dicatat pada neraca. SFAS 133 mensyaratkan kriteria pengukuran instrumen hedging yang akan dicantumkan dalam neraca, yaitu:

a. Semua derivatif harus diakui sebagai aktiva atau hutang dengan pengukuran pada nilai yang wajar (fair value yaitu nilai pasar).

b. Derivatif boleh dirancang sebagai satu fair value hedge. Derivatif ini boleh meng-hedge tem tunggal (aktiva, hutang, atau satu komitment perusahaan) atau satu portofolio atas item yang sama, yang nilai wajarnya harus dapat - diukur dan berkorelasi tinggi dengan perubahan atas nilai wajar dari hedging derivatives yang di-hedge tersebut. Perubahan dalam nilai wajar item hedge ini akan diakui dalam laba bersih.

c. 'Derivatif boleh didisain sebagai satu cash flow hedge, jika dimaksudkan untuk meng-hedge satu forecasted transaction yang mungkin terjadi. Arus.kas atas hedging deri-vatives harus diekspektasi untuk menutup elemen risiko yang sama atas hedge transaction. Satu transaksi boleh mempunyai beberapa elemen risiko, tetapi satu derivatif hanya boleh meng-hedge satu risiko saja. Perubahan nilai pasar atas derivatif harus diakui dalam comprehensive income sampai dengan tanggal yang diproyeksikan atas forecasted transaction. Pada akhir jatuh temponya, laba atau kerugian yang terakumulasi harus 
dilaporkan dalam laba bersih. Aplikasi yang paling umum atas nilai wajar akuntansi hedge akan menjadi investasi atau hutang untuk tingkat bunga obligasi yang bersifat tetap. Akuntansi ini tidak dapat digunakan untuk menghedge atas portofolio hutang yang jatuh tempo, lease, àsuransi, hutang, atau investasi dengan equity method.

d. Derivatif didisain sebagai satu hedge atas investasi bersih pada operasi perusahaan di negara lain yang memenuhi syarat untuk hedge accounting, meskipun untuk porto-folio belum diatur dalam standár ini. Perubahan nilai pasar atas derivatif ini harus dilaporkan sebagai bagian dari akumulasi komponen adjusment translation dari ekuitas.

e. Perubahan dalam nilai wajar atas derivatif yang bukan bagian dari strategi hedging harus dicatat dalam laba bersih.

Komitmen perusahaan yang melakukan hedging secara relatif bukan sesuatu yang bersifat kontroversial, karena ada beberapa alasán yang pasti bahwa transaksi yang di-hedged akan terjadi. Peristiwa yang diekspektasi akan terjadi dan perlu dilindungi ini sering dikatakan sebagai forecasted transaction. Namun demikian, hedging atas transaksi yang telah diantisipasi (forecasted) ini dapat menimbulkan pertanyaan tentang apa yang terjadi jika transaksi yang hedge tidak terjadi. Hedge atas forecasted transaction adalah lebih bersifat subyektif, dan manajemen tidak boleh mengkarakteristikannya sebagai aktivitas spekulatif. Pembahasan akuntansi dalam standar akuntansi yang ada menurut Stewart (1989) tidak menyatakan adanya standar pelaporan yang jelas atas forward tingkat bunga, option, dan swaps tingkat bunga. Dia menganggap bahwa keberadaan standar-standar tersebut tidak konsisten.

Beberapa standar akuntansi yang berkenaan aktivitas hedging sebelum terbitnya SFAS 133 menunjuk-kan adanya perbedaan yáng cukup signifikan. SFAS 80 mengarahkan akuntansi hedge dengan satu pendekatan enterprise, sedangkan SFAS 52 harus berdasarkan satu pendekatan transaksi, sehingga perlakuan atas transaksi keuntungan dan kerugian yang secara ekonomi sama dapat diperlakukan secara berbeda pengakuannya. Pada SFAS 80 , kontrak future boleh diperlakukan sebagai hedge atas forecasted transaction, tetapi SFAS 52 tidak membolehkan sebagai hedge. Demikian juga, transaksi derivatif atas perubahan pertukaran mata uang yang berbeda yang korelasinya tinggi menurut SFAS 80 boleh diakui sebagai hedge, tetapi menurut SFAS 52 tidak boleh diakui sebagai hedge karena dianggap sebagai imperfect hedging.

\section{F. PENGUNGKAPAN ATAS AKTIVITAS HEDGING}

Salah satu bagian laporan keuangan yang dianggap penting adalah catatan atas laporan keuangan. Istilah lain dari catatan atas laporan keuangan adalah pengungkapan (disclosure). Prinsip disclosure yang sesuai dengan standar akuntansi keuangan adalah prinsip disclosure layak (fair/disclosure) (Belkoui 1992). Karena prinsip disclosure penuh (full disclosure) dan disclosure cukup (adequate disclosure) sering menjadi pertentangan diantara investor dan manajemen perusahaan. Prinsip disclosure penuh dianggap oleh perusahaan tèrlalu ber̂lebihan, sebaliknya prinsip disclo-sure cukup dianggap oleh investor, tidak memenuhi syarat karena terlalu sedikit yang diungkapkan. 
Prinsip disclosure cukup dianggap kurang memadai karena dibuat hanya untuk memenuhi syarat minimum dalam pengungkapannya, sehingga hal ini dapat mengurangi substansi informasi yang dibutuhkan oleh investor untuk kepentingan pembuatan keputusan investasinya. Dan kondisi ini sering kali dianggap menyesatkan investor. Prinsip disclosure yang penuh mensyaratkan bahwa laporan keuangan harus didisain dan disiapkan untuk memberikan gambaran secara akurat atas semua kejadian ekonomik yang mem-pengaruhi perusahaan selama periode tertentu dan berisi informasi yang cukup untuk membuat laporan keuangan berguna dan tidak menyesatkan bagi investor. (Belkaoui 1992). Secara lebih eksplisit, prinsip ini mengimplikasikan bahwa tidak ada informasi tentang substansi atau penting bagi investor yang akan dihilangkan atau disembunyikan. Persyaratan disclosure penuh ini akan menunjukkan penyajian informasi yang lengkap dan komprehensip. Namun demikian, prinsip disclosure penuh ini oleh manajemen dianggap tidak efektif. Karena mengandung risiko kelebihan informasi (information overload risk) yang dapat merugikan perusahaan sendiri. Kerugian perusahaan atas informasi yang berlebihan ini menurut Fóster (1986) meliputi: (1) dapat meningkatkan biaya pengumpulan dan pemrosesan data, (2) dapat menimbuikan biaya litigasi (litigation costs), yaitu biaya yang terjadi karena penyelesaian suatu masalah yang ditimbulkan oieh adanya disclosure laporan keuangan, (3) dapat menimbulkan biaya politik, yaitu biaya yang terjadi karena adanya campur tangan pemerintah yang disebabkan oleh penerbitan disclosure, (4) dapat menimbulkan biaya ketidakberuntungan persaingan (competitive disadvantage cost), yaitu suatu kerugian perusahaan yang ditimbülkan oieh adanya disclosure perusahaan yang dimanfaatkan oleh perusahaan pesaingnya, (5) dapat menimbulkan kerugian yang disebabkan oleh perilaku manajer yang menjadi terbatas karena manajer terlalu berpedoman pada informasi yang telah dinyatakan dalam disclosure sehingga perilakunya tidak fleksibel.

Dalam kaitannya dengan aktivitas hedging, standar akuntansi yang ada tidak secara tegas mewajibkan perusahaan untuk mengungkapankannya dalam laporan keuangan, tetapi hanya bersifat anjuran. Oleh karena itu, perusahaan harus berhati-hati dalam membuat disclosure agar tidak sampai menimbulkan satu kerugian karena terlalu banyak informasi yang diungkapkan atau terlalu sedikit informasinya. Jika informasi yang diungkapkan terialu sedikit, maka hal ini dapat merugikan kepentingan investor. Tujuan disclosure atas aktivitas hedging menurut White dkk. (1997) adalah untuk memberikan pemahaman pada pembaca laporan' keuangan tentang: (a) risiko yang dihadapi perusahaan, (b) aktivitas manajemen dalam mengelola risiko termasuk instrumen derivatif yang digunakan, (c) pengaruh atas aktivitas manajemen risiko perusahaan pada laporan keuangan, (d) perbedaan antara hedging akuntansi dan hedging ekonomik. Walaupun standar akuntansi yang ada tidak secara tegas dalam mewajibkan perusahaan untuk membuat disclosure atas aktivitas hedging, namun menurut penulis standar akuntansi yang ada sudah cukup jelas menunjukkan kriteria disclosure yang seharusnya ada dalam laporan keuangan. SFAS 107 dan 133 mensyaratkan disclosure atas nilai pasar untuk semua instrumen keuangan, kecuali untuk kontrak asuransi, lease, investasi ekuitas, dan piutang dan hutang usaha. Perusahaan harus mengungkapkan asumsi dan metode yang digunakan 
dalam mengembangkan estimasi nilai yang wajar. Disclosure naratiftambahan juga diminta jika nilai wajar atas instrumen aktivitas hedging tidak dapat diprediksi. Standar ini tidak mengkhususkan atau membatasi metode estimasi tetapi bermaksud meminta informasi kualitatif atas metode estimasi yang digunakan. Substansi disclosure yang disyaratkan tentang derivatif dan aktivitas manajemen risiko menurut SFAS 107 meliputi: (a) diskripsi atas aktivitas manajemen risiko dan pengelompokan derivatif yang digunakan untuk aktivitas hedging tersebut. (b) keuntungan dan kerugian (dari hedge dan item hedge) yang dimasukkan dalam laba bersih. (c) keuntungan dan kerugian yang tidák diakui dalam laba, dan disclosure atas jumlah dan rekening di neraca tempatangka dilaporkan.

Standar akuntansi lainnya adalah SFAS 119 yang mengatur disclosure secara lebih detail tentang kontrak forward. Standar ini mensyaratkan disclosure atas kontrak forward meliputi:

1. Untuk derivatif yang dipegang untuk diperdagangkan, disclosure harus menujukkan: (a) rata-rata nilai wajarnya, (b) akhir periode dari nilai wajamya, (c)keuntungan atau kerugian bersih yang tidak tergabung dalam kelompok aktivitas bisnis, atau risiko bisnis.

2. Untuk derivatif yang dipegang tidak untuk diperdagangkan, disclosure harus mencantumkan: (a) tujuan perusahaan, strategi dan pengelompokan derivatif yang digunakan, (b) kebijakan pengukuran dan pengakuan yang digunakan untuk tujuan akuntansi, (c) rekening pelaporan di neraca atas jumlah yang diakui. (d) hedge atas forecasted transaction, termasuk metode hedging, jatuh tempo transaksi yang bersangkutan, keuntungan dan kerugian hedging yang ditang-guhkan, dan peristiwa yang akan merubah pengakuan yang ditangguhkan tersebut.

3. Untuk derivatif yang tidak termasuk dalam kelompok instrumen keuangan dengan risiko off-balanced sheet (SFAS 105), disclosure harus menyajikan tentang: (a) bentuk, kontrak, atau jumlah penduganya. (b) syarat dan sifatnya, termasuk risiko kredit dan risiko pasar, persyaratan tunai, dan metode akuntansinya.

4. Standar ini juga menganjurkan (tetapi tidak mewajibkan) penyajian informasi kuantitatif tentang risiko atas instrumen keuangan derivatifnya. Kemungkinan disclosure ini akan meliputi: (a)data detail yang berkénaan dengan posisi dan transaksinya, (b)pengaruh perubahan yang diekspektasi dalam harga pasar, (c)analisis selisih atas interest rate repricing atau tanggal jatuh temponya, (d) data duration, (c)nilai risiko perusahaan.

Instrumen keuangan sebagai hasil suatu perekayasaan keuangan - mempunyai jenis yang sangat beragam. Beberapa jenis instrumen keuangan dapat diperdagangkan di pasar sekuritas, yang secara úmum bila ditelusuri berasal hanya dari 4 (empat) jenis saja, yaitu: (1) kontrak forward, (2) kontrak future, (3) kontrak swap, (4) kontrak option. Dari 4 jenis instrumen ini dapat dibentuk banyak kombinasi kontrak baru, yang pembentukannya menggunakan metode Building Block.

Tujuan utama pembentukan instrumen ini adalah untuk mengendalikan risiko 
$\therefore$ keuangan perusahaan agar dapat mencapai perfect hedge. Risiko keuangan perusahaan dapat disebabkan oleh adanya perubahan dalam harga komoditas, tingkat bunga, dan tingkat pertukaran mata uang, serta nilai pasar yang arahnya tidak searah dengan kebijakan manajemen perusahaan. Tidak semua instrumen keuangan dapat memenuhi syarat, yang sesuai dengan standar akuntansi sebagai satu item hedge untuk dicantumkan dalam neraca. Hal ini disebabkan oleh sifat transaksi yang mendasari terjadinya hedge tersebut. Keberadaan standar akuntansi saat ini tidak menyatakan secara tegas dalam mewajibkan perusahaan untuk membuat disclosure atas aktivitas hedgingnya dalam laporan keuangan. Hal ini dikarenakan oleh prinsip disclosure yang ada masih dipertentangkan oleh pihak yang berkepentingan yaitu antara manajemen perusahaan dengan investor, terutama antara prinsip disclosure (full disclosure) penuh dan disclosure cukup (adequate disclosure). Akan tetapi, standar akuntansi tersebut telah menyatakan secara jelas kriteria-kriteria yang harus dipenuhi dalam membuat disclosure atas aktivitas hedging. Standar akuntansi yang ada telah mengalami beberapa kali perubahan khususnya yang berkaitan perlakuan akuntansinya. 
Belkaoui, A:R. 1992. Accounting Theóry, Edisi Ketiga, Boston: Harcourt Brace Jouanovich. Chew Jr. 1998. The New Corporate Finance-Where Theory Meets Practice, Edisi Kedua, Malaysia: Imin Mc Graw-Hill.

Financial Accounting Standard's Boàrd'(FASB), Statement of Financial Accounting Standards (SFAS) No. 52. 1981.

Foreign Currency Transiation. Norwalk, CT: FASB. Financial Accounting Standards.(SFAS) Nó. 80. 1984. Statement of

Accounting for Futures Contracts:-Norwalk,-CT: FASB. ment of Financial Accounting Standards (SFAS) No. 105. 1990.

. Risk and Financiallnstruments with Concentrations of Credit Risk. Nonwalk, CT: FASB. Statement of Financial Accounting Standards (SFAS) No. 107. 1991.

Disclosure about Fair Value of Financial Instruments. Norwalk, CT: FASB. Statement of. Financial Accounting Standards (SFAS) No. 119. 1994.

- Disclosure about Derivative Financial Instruments and Fair Value of Financiải Instruments. Norwalk, CT: FASB. counting Standards (SFAS) No. 133. 1998. Statement of Financial Ac-

Accounting for Derivative Instruments and Hedging Activities. Norwalk, Finnerty, John. 1988.

Financial Engineering In Corporate Finance: An Overview. Financial Management (Winter): 14-33. Foster, George. 1986.

Financial Statement Analysis, New Jersey: Prentice Hall, inc. Hull, John C. 1997. Options, Futures, and Other Derivatives, Third Edition, NJ: Prentice Hall international, Inc. 1998.

Introduction To Future and Options Market, NJ: Prentice-Hall Intema tional, Inc: Marshall; John-F;, dan Vipul K-Basal: 1992.

Financial Engineering-A Complete Guide To Financial Innovation, $\mathrm{N} N \mathrm{~N}$ Wै York. Allyn \& Bacon, Inc. Miller, Merton H. 1992.

i : $\because-\cdots, \quad r$, Financial Innövation: Achievements and Prospects Dalam Donald H. Smith, Den 1993.

- 1998. 今

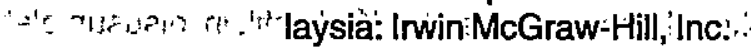

"14.11, Smithson;:Chàrles W., dan Clifford W. Smith:-1990: Strategic Risk Man-

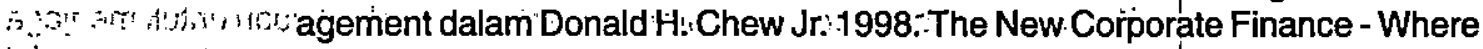
if $\quad \therefore$ Theory Meets Practice, Edisi Kedua, Malaysia: Irwin McGraw-Hill, Inc.

15 :

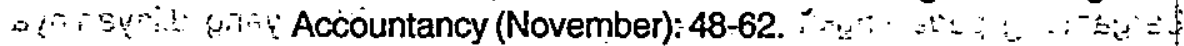

in's a

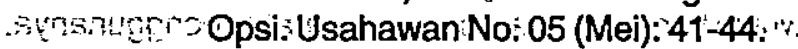

arot a itn. I

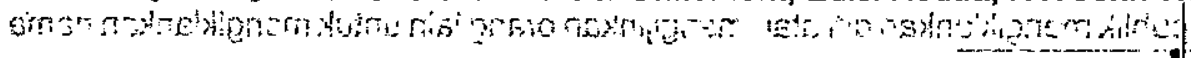

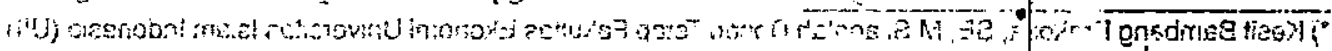

